\title{
KAJIAN KONSEP ARSITEKTUR FUTURISTIK PADA BANGUNAN KANTOR
}

\author{
${ }^{1}$ Farhan Fauzi, ${ }^{2}$ Wafirul Aqli \\ 1-2Universitas Muhammadiyah Jakarta, Jakarta, Indonesia \\ 2015460061@ftumj.ac.id ${ }^{1}$
}

\author{
Informasi Naskah \\ Diterima: 06/11/2020; Disetujui terbit: 29/12/2020; Diterbitkan: 29/12/2020; \\ http://iournal.uib.ac.id/index.php/iad
}

\begin{abstract}
ABSTRAK
Kantor merupakan bangunan komersial dengan fungsi utama menyediakan ruang usaha bagi kegiatan perkantoran maupun bisnis di kota-kota dengan tingkat perekonomian yang cukup tinggi. Kebutuhan terhadap perkantoran atau office building identik dengan prestise dan perkembangan dari sebuah perusahaan. Konsep Futuristik Mempunyai arti mengarah atau menuju masa depan, konsep Arsitektur futuristik memiliki prinsip- prinsip yang akan menggambarkan bahwa perencanaan dan pembangunannya tidak didasarkan oleh sesuatu yang terkait dengan masa lalu, akan tetapi mencoba untuk menggambarkan masa depan. Bangunan harus dapat mengikuti dan menampung tuntutan kegiatan yang pasti selalu berkembang. Diharapkan dengan adanya penelitian ini dapat menjelaskan dan memahami prinsip-prinsip Arsitektur futuristik
\end{abstract}

Kata Kunci: Arsitektur, Futuristik, Kantor

\begin{abstract}
Offices are commercial buildings with the main function of providing business space for office and business activities in cities with high economic levels. The need for offices or office buildings is identical to the prestige and development of a company. Futuristic concepts tend to lead or towards the future, the concept of futuristic architecture has principles that will illustrate that planning and construction are not based on something related to the past, but will try to describe the future. Buildings must follow and remember activities that are always developing. It is hoped that this research can explain and understand the principles of futuristic architecture.
\end{abstract}

Keywords: Architecture, Futuristic, Office

\section{Pendahuluan}

Pertumbuhan ekonomi di Indonesia saat ini berkembang sangat pesat, pertumbuhan ini disebabkan oleh munculnya perusahaan - perusahaan baru yang menjalankan bisnisnya di kota - kota besar, perusahaan baru ini memerlukan tempat untuk beraktifitas, seperti pada kawasan CBD Jakarta permintaan perkantoran pada kawasan tersebut mengalami peningkatan pada 2018 menjadi 150.000 meter persegi. Sebelumnya permintaan ruang kantor pada 2017 berada dibawah 100.000 meter persegi. Berdasarkan data Colliers, pada tahun 2018-2020, tambahan pasokan ruang kantor di kawasan CBD diperkirakan mencapai 1,2 juta $\mathrm{m}^{2}$. Sementara untuk wilayah diluar CBD, akan terdapat 21 perkantoran dengan luas ruang kantor sebesar $659.900 \mathrm{~m}^{2}$ pada 2018-2020. (Hanly,2019) 
Futuristik sejalan dengan perkembangan teknologi, dengan semakin maju teknologi yang diciptakan manusia, maka keberadaan futuristik akan semakin berkembang. Karakteristik arsitektur futuristik pada tampilan bangunan diantaranya yaitu gubahan massa yang dinamis dan ekspresif dengan bentuk desain yang praktis dan fleksibel, tampil lebih sederhana tetapi berani menggunakan corak warna maupun permainan garis miring, serta penggunaan teknologi terbaru pada material dan struktur.

Bangunan perkantoran dengan konsep arsitektur futuristik dapat menjadikan bangunan mempunyai ciri khas dan menambah nilai bangunan agar dapat bersaing. Permasalahan dan fakta yang ada menunjukkan bahwa desain futuristik dipilih sebagai solusi untuk menjawab permasalahan yang ada. Desain futuristik yang diterapkan pada bangunan perkantoran dengan memperhatikan kebutuhan ruang dan tampilan bangunan. Tujuan dari penelitian terhadap konsep arsitektur Futuristik pada bangunan Perkantoran ini diantaranya adalah (1) Memahami prinsip-prinsip yang berlaku dalam terciptanya arsitektur futurstik, (2) Memahami implementasi arsitektur futuristik pada bangunan perkantoran.

\section{Kajian Pustaka}

Futuristik merupakan suatu paham kebebasan dalam mengungkapkan atau mengekspresikan ide atau gagasan ke dalam suatu bentuk tampilan yang tidak biasa, kreatif dan inovatif. Hasil dari futuristik ini adalah sesuatu yang dinamis, selalu berubahubah sesuai keinginan dan zamannya.

\subsection{Futuristik}

Futurisme adalah bagaimana menangkap unsur gerak dan kecepatan ke dalam lukisan dengan memanfaatkan prinsip aneka tampak.Futurisme merupakan aliran seni yang mendukung perkembangan tipografi sebagai unsur ekspresi dalam design. Aliran ini mengatakan keindahan gerak dan dipandang sebagai pendobrak aliran Kubisme yang dianggap statis dalam komposisi, garis dan pewarnaan. Objek Lukisannya Futurisme mengabdikan diri pada gerak. (Ariesa Pandanwangi, 2019)

Prinsip-prinsip futuristik yaitu :

1. Karya seni menangkap unsur gerak dan kecepatan.

2. Memanfaatkan prinsip aneka tampak atau ( multiple viewpoints ).

3. Menggunakan tipografi sebagai unsur ekspresi dalam desain.

4. Memperhatikan tentang kedinamisan, kedisiplinan, dan gaya untuk mengekspresikan kecepatan dan kesamaan waktu.

5. Konsep ruang dan waktu melebur atau tidak ada.

6. Memiliki tema dinamisme universal.

7. Keadaan objek yang bergerak digambarkan secara berlebihan.

8. Bertolak pada sensasi optik, teknologi dan kehebatan eksistensi mesin - mesin.

9. Membentuk gambar sintesa yang menunjukan fase - fase yang berjajar.

10. Lukisan adalah rumusan artistik yang harus merekam kompleksnya realitas.

11. Memperlihatkan bentuk-bentuk realitas yang berbeda, yang dekat dan yang jauh, benda-benda yang terlihat dan terasa, saling menembus, dan digambarkan dalam waktu yang sama.

12. Penyatuan karakter dari elemen-elemen yang berbeda-beda dalam sebuah acuan, dan penyusunannya karyanya sebagai suatu kesatuan.

13. Memiliki ide-ide seperti ketertutupan, ketidaksabaran, ekstrim dalam hubungan langsung dengan nilai-nilai futurisme. 
14. Karakteristiknya juga meliputi garis-garis yang tidak rata yang mengkomunikasikan energy dari gerakannya.

15. Pandangan karya yang mementingkan masa depan.

\subsection{Arsitektur Futuristik}

Futuristik artinya bersifat mengarah atau menuju masa depan, citra futuristik pada bangunan sendiri memiliki arti yang mengesankan bahwa bangunan itu berorientasi ke masa depan atau bangunan itu selalu mengikuti perkembangan jaman serta tuntutan dan persyaratan pada era bangunan itu sendiri. ciri-ciri dari arsitektur futuristik dijabarkan dalam buku Eero Saarinen Biography karya Jayne Merkel (2014)

Eero Saarinen adalah seorang arsitek dan perancang industri Finlandia-Amerika yang terkenal karena gaya neo-futuristiknya. Saarinen dikenal karena merancang Bandara Internasional Washington Dulles di luar Washington, D.C., Pusat Penerbangan TWA di Kota New York, dan Gateway Arch di St. Louis, Missouri. Berikut adalah ciri-ciri arsitektur futuristik menurut Eero Saarinen,(Fachri Zahari, 2017)

1. Memiliki gaya Universal atau seragam, dengan model arsitektur yang dapat menembus budaya dan geografis tertentu.

2. Berupa khayalan yang idealis.

3. Memiliki bentuk tertentu yang fungsional sehingga mengikuti fungsi.

4. Less is more, semakin sederhana merupakan suatu nilai tambah terhadap gaya arsitektur Futuristik.

5. Ornamen dianggap sebagai suatu kejahatan sehingga perlu ditolak, penambahan ornamen dianggap suatu hal yang tidak efisien karena dianggap tidak memiliki fungsi.

6. Bersifat Singular atau tunggal, yaitu tidak memiliki suatu ciri individu dari arsitek, sehingga tidak dapat dibedakan antara arsitek yang satu dengan yang lainnya dan lebih bersifat seragam.

7. Nihilism, merupakan penekanan perancangan yang ada pada ruang, maka rata-rata desain menjadi polos, sederhana dengan penggunaan bidang-bidang kaca lebar.

8. Kejujuran bahan yaitu mengekspos jenis bahan atau material yang digunakan dan ditampilkan seadanya, tidak ditutup-tutupi atau dikamuflase sedemikian rupa hingga hilang karakter aslinya. Bahan-bahan utama yang digunakan antara lain beton, baja dan kaca. Material-material tersebut dimunculkan apa adanya untuk merefleksikan karakternya yang murni.

Dengan melihat kajian mengenai futuristik dan ciri-ciri arsitektur futuristik menurut Eero Saarinen, maka diambil kesimpulan pedoman dalam perencanaan berdasarkan ungkapan futuristik, yaitu :

a. Gerak Dan Kecepatan

Mempunyai konsep masa depan terutama sesuai dengan paradigma perkembangan arsitektur. Membuat terasa seperti berada di tempat lain

b. Melawan Arus

Bentuk yang didapat bukan bentuk-bentuk tertentu saja, tetapi bentuk bebas yang menentang klasifikasi dan bahkan menentang gravitasi.

c. Kejujuran Bahan

Menggunakan bahan dimunculkan apa adanya untuk merefleksikan karakternya yang murni, seperti beton yang dibiarkan terekspose serta bahan-bahan prefabrikasi dan bahan-bahan baru, seperti kaca baja aluminium, dll. 
d. Dinamis

Dinamis memiliki karakter bangunan yang melengkung, miring yang ditunjang dengan struktur yang dirancang khusus Memunculkan bentuk-bentuk baru dari arsitektur yang tidak bisa diduga sebelumnya, dinamis sebagai konsekuensi dari perubahan.

e. Menggunakan Kemajuan Teknologi

Memanfaatkan kemajuan di era teknologi melalui struktur dan konstruksi, menggunakan teknologi konstruksi secara ekstrim,

f. Nihilisme

Nihilisme juga untuk perancangan menjadi polos simple, dengan pemakaian kaca lebar,jedis bahan yang di pakai material diekspos secara polos juga dan di perhatikan apa adannya. Dalam arsitektur Futuristik, konsep desain tak berpaku pada material, atau aturan aturan yang apapun selagi masih dalam konsep menuju masa depan.

g. Gaya Universal

Bentuk bangunannya umum tanpa membedakan, dengan model arsitektur yang dapat menembus budaya dan geografis tertentu.

h. Khayalan yang idealis

Membuat kebaruan dalam hal bentuknya, Contoh seperti seperti beton yang berat tetapi harus bebas dan ringan melupakan akan adanya gravitasi khayalan yang idealis membawa kepada sesuatu hal yang baru, sehingga beton yang berat menjadi sesuatu yang lain.

\section{Metode Penelitian}

Metode yang digunakan dalam penelitian ini adalah metode penelitian kualitatif, yaitu sebuah metode yang sifatnya deskriptif. Dimana prosesnya menggunakan analisis, mengacu pada data yang dikumpulkan, dan memanfaatkan teori yang ada sebagai bahan pendukung, lalu menghasilkan suatu teori. Berikut adalah tahapan-tahapan nya :

\subsection{Pendataan}

Dalam proses pendataan terdiri dari 2 sumber yaitu studi literature dan studi lapangan

a. Studi Literatur

Studi literatur tentang arsitektur analogi menurut beberapa ahli, dari beberapa pendapat tersebut kemudian di komparasikan Antara satu dengan yang lain nya dan dicari kesamaan nya untuk dijadikan acuan penelitian pada bangunan objek studi. Pengumpulan data memalui pengkajian literatur ini dapat ditempuh dengan membaca dan mengumpulkan teori yang ada. Dapat diperoleh dari berbagai sumber, seperti: Jurnal, tesis, buku, artikel, skripsi, catatan harian , arsip foto dan literatur lainnya. Sumber literatur tersebut, dapat dilakukan dengan mengunjungi perpustakaan, toko buku, internet.

b. Studi lapangan

Pengumpulan semua data yang ada di lapangan, pengumpulan data dilakukan dengan cara mendokumentasikan kondisi di lapangan mencatat hal-hal yang di perlukan, sketsa, dan wawancara terhadap pengelola, dan dengan wawancara terhadap petugas pengelola. Dengan menggunakan seluruh pancaindera kita, kita dapat melihat, merasakan, mendengar dan memahami secara langsung apa saja yang terdapat dilapangan. Hal ini berguna untuk memperoleh informasi guna menjawab permasalahan penelitian. Hasil yang didapat dari tinjauan langsung ke 
lapangan merupakan suatu aktifitas, perasaan emosi, detail kejadian, dan kondisi tertentu. Tinjauan lapangan dilakukan untuk memperoleh gambaran suatu peristiwa secara nyata sebagai acuan untuk menjawab semua pertanyaan penelitian.

\subsection{Analisis Data}

Berikut merupakan tahapan dalam analisa:

1. Merangkum teori-teori tentang arsitektur Futiristik

2. Menganalisis penerapan konsep arsitektur analogi pada 1 studi kasus
a. Mengidentifikasi dan mendeskripsikan objek penelitian terpilih terkait konsep arsitektur futuristik
b. Menafsirkan kaitkan prisip-prinsip arsitektur Futuristik dengan hasil identifikasi terhadap tiga studi kasus
c. Mendeskripsikan hasil analisis

Untuk lebih jelas nya dapat dilihat pada gambar 1

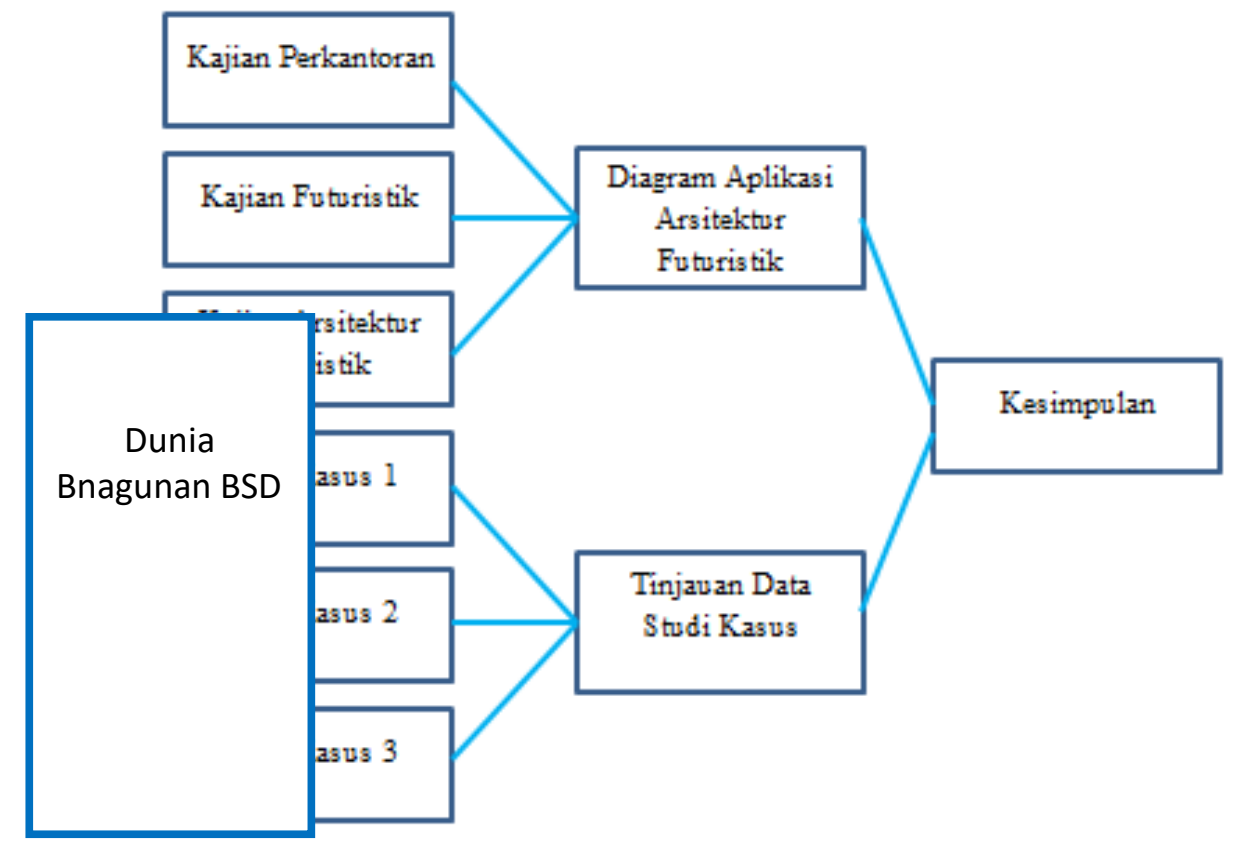

Gambar 1. Skema Proses Analisis

Sumber :Dokumen Pribadi, 2020

\section{Hasil dan Pembahasan}

Dunia bangunan yang berlokasi di BSD ini merupakan bangunan Kantor dan showroom, yang dari elemen bangunan exterior dan interiornya terdapat prinsip dari aritektur futuristik, Berikut adalah hasil dan pembahasan mengenai prinsip prinsip yang ada pada bangunan ini.

\subsection{Gerak dan Kecepatan}

Pada bangunan kantor dunia bangunan sifat gerak kecepatan yag dapat ditemukan pada bentuk facade, dengan material facade menggunakan aluminium composite panel yang membentuk jendela menjadi garis yang menekuk memanjang yang dapat diterjemahkan sebagai gerak dan kecepatan hal ini dapat dilihat pada gambar 2 yang menggambarkan bagaimana sebuah elemen facade bangunan memenuhi kriteria gerak dan kecepatan. 


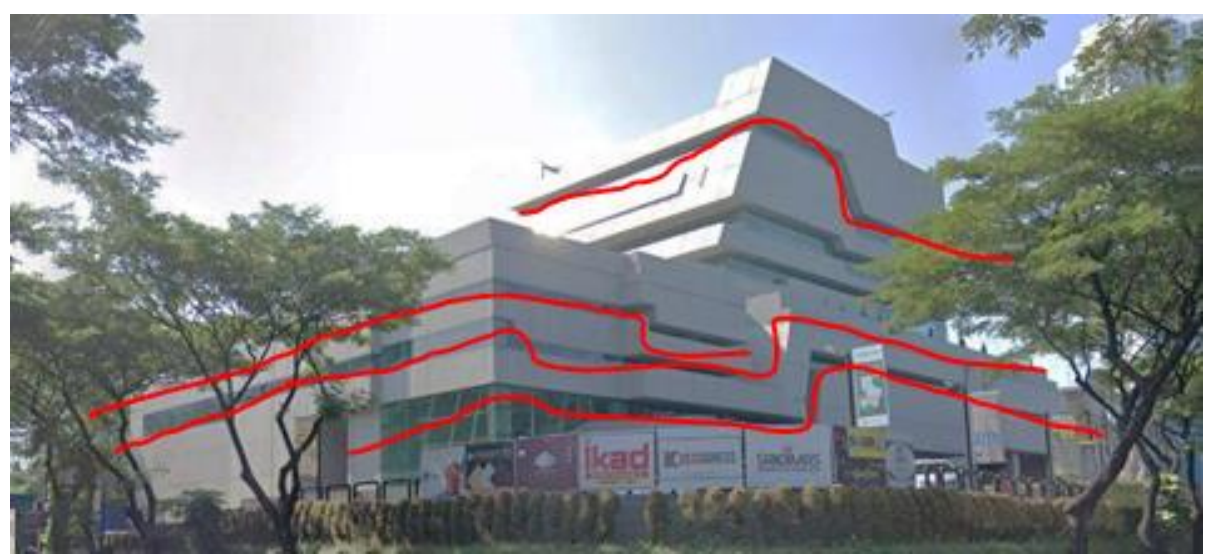

Gambar 2 Klasifikasi Gerak dan Kecepatan Pada Gedung Dunia Bangunan Sumber : Dokumentasi Pribadi, 2020

\subsection{Melawan Arus}

Bentuk dari bangunan ini berbeda dengan bentuk gedung perkantoran lainnya dilihat dari lantai pada office space yang miring yang melawan arus dari bentuk office pada umumnya dapat dilihat pada gambar 3

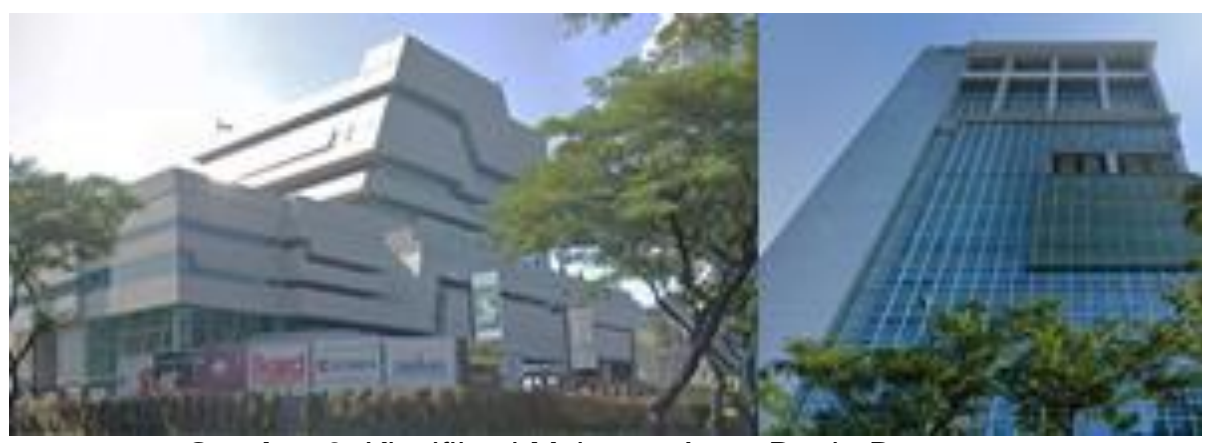

Gambar 3. Klasifikasi Melawan Arus Dunia Bangunan Sumber : Dokumentasi Pribadi, 2020

\subsection{Kejujuran Bahan}

Pada bangunan ini kejujuran badahan terlihat dari facade bangunan yang menggunakan material aluminium composite panel dan kaca tanpa di finish atau dicat kembali, dengan warna facade dominan putih dan kaca jndela yaang berwarna hijau ini adalah warna asli dari bahan atau material yang digunakan bisa dilihat dari gambar 4 dibawah ini.

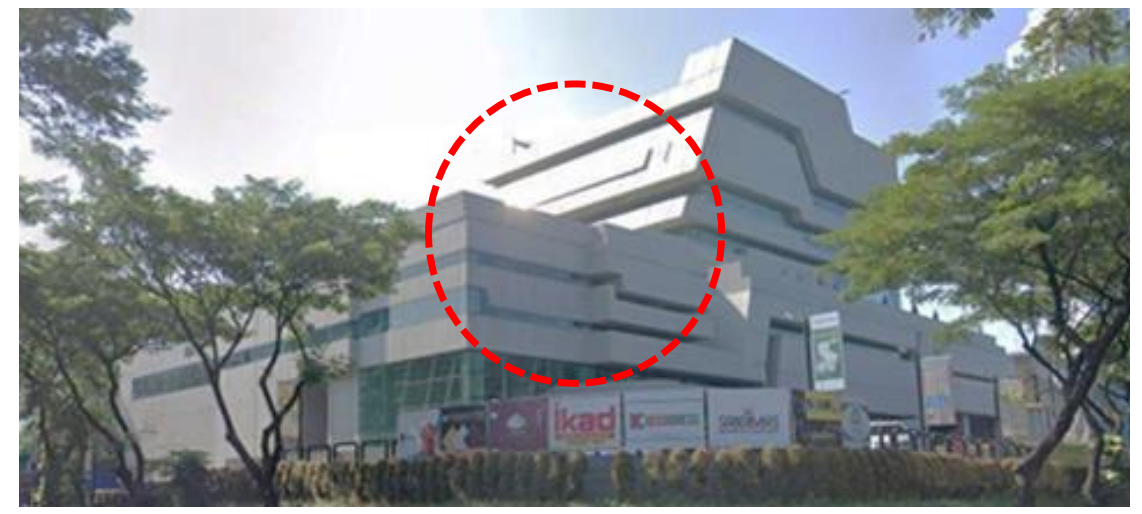

Gambar 4. Klasifikasi Kejujuran Bahan Dunia Bangunan

Sumber : Dokumentasi Pribadi, 2020

170 IJAD- Vol.01/No.02, Desember 2020 


\subsection{Dinamis}

Dunia bangunan dirancang dengan bentuk yang dinamis pada Gambar 5 terlihat komposisi dari ACP dan jendela yang memiliki bentuk dan karakter cenderung tidak beraturan serta memiliki tatanan sudut yang bervariasi.

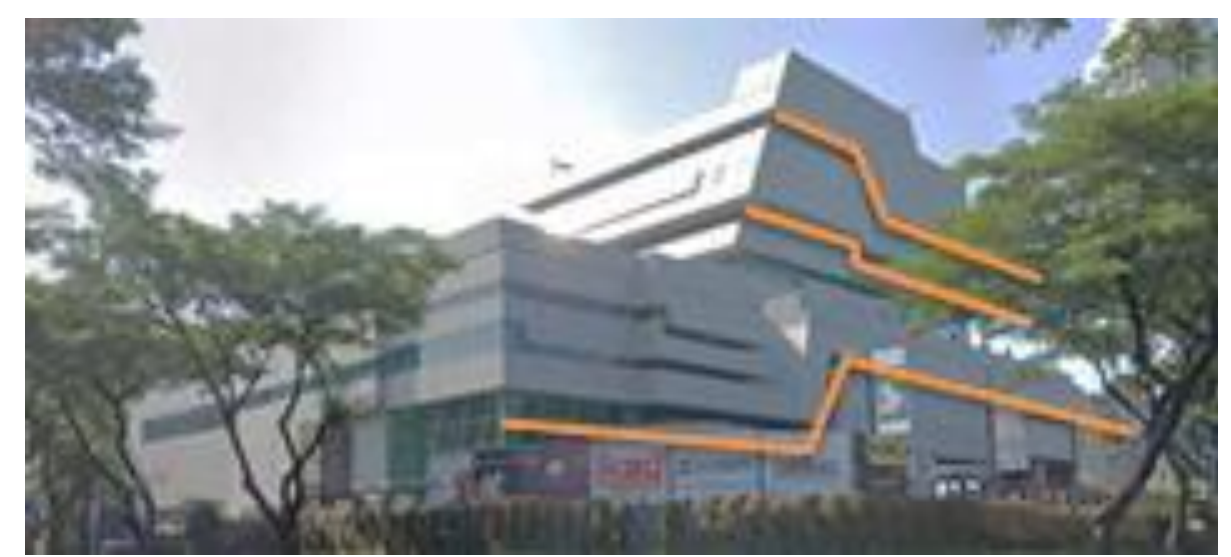

Gambar 5. Klasifikasi Dinamis Dunia Bangunan Sumber : Dokumentasi Pribadi, 2020

\subsection{Menggunakan Kemajuan Teknologi}

Kemajuan teknologi pada bangunan Dunia bangunan BSD tidak terlihat di elemen interior exterior.

\subsection{Nihilisme}

Nihilisme diartikan sebagai pencapaian ruang yang polos, kosong, ataupun simpel, pada bangunan Dunia bangunan BSD karakteristik nihilsme terlihat pada penggunaan warna yang polos yaitu perpaduan antara warna putih dan hijau sangat menunjukan bahwa bangunan ini bersifat nihilsme terlihat pada Gambar 6

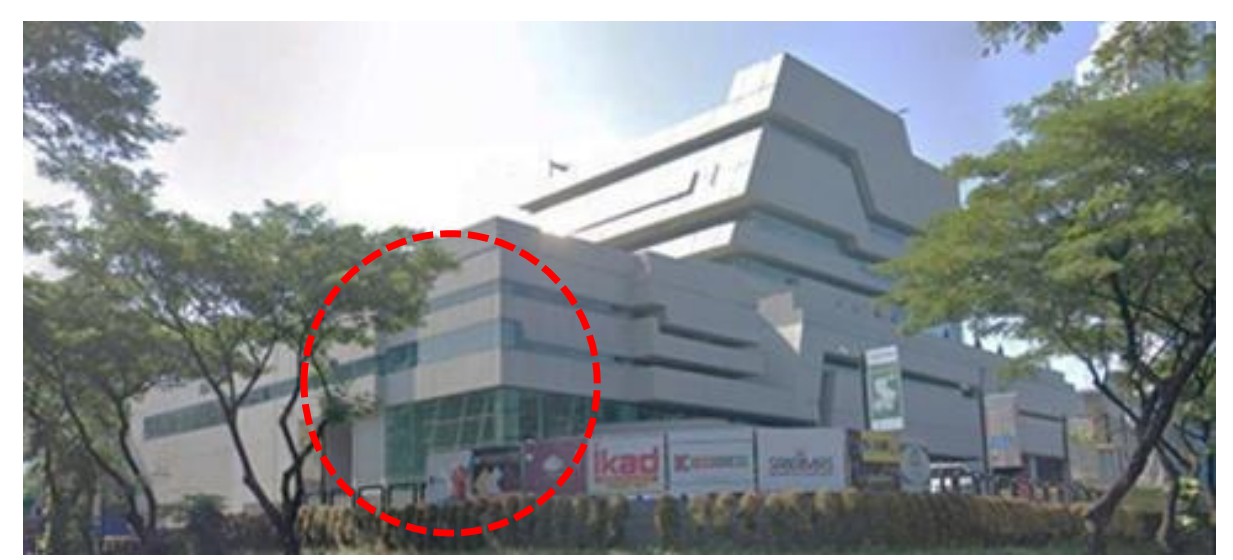

Gambar 6. Klasifikasi Nihilisme Dunia Bangunan Sumber : Dokumentasi Pribadi, 2020

\subsection{Gaya Universal}

Universal komposisi dalam satu massa bangunan terlihat bervariasi dan tidak membedakan, dan Setiap fungsi pada bangunan harus mudah dimengerti oleh penggunanya berdasarkan pengalaman, pengetahuan, bahasa, kemampuan, dan tingkatan intelektualitasnya terlihat pada Gambar 7 


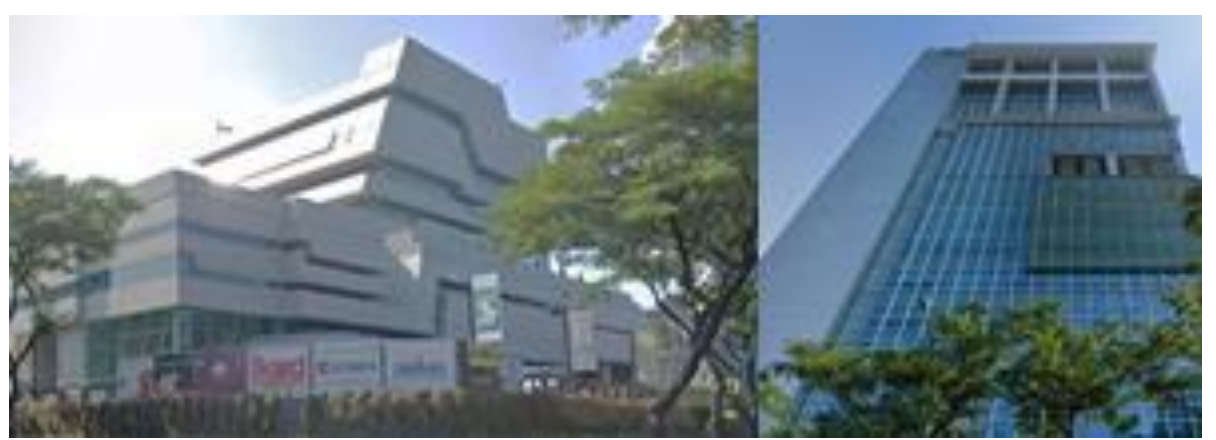

Gambar 7. Klasifikasi Universal Dunia Bangunan Sumber : Dokumentasi Pribadi, 2020

\subsection{Khayalan yang idealis}

Khayalan yang idealis terlihat dari bentuk bangunan yang membuat kebaruan dalam hal bentuknya , sangat jelas terlihat jika dibandingkan dengan gedung perkantoran pada umumnya terlihat dari Gambar 8

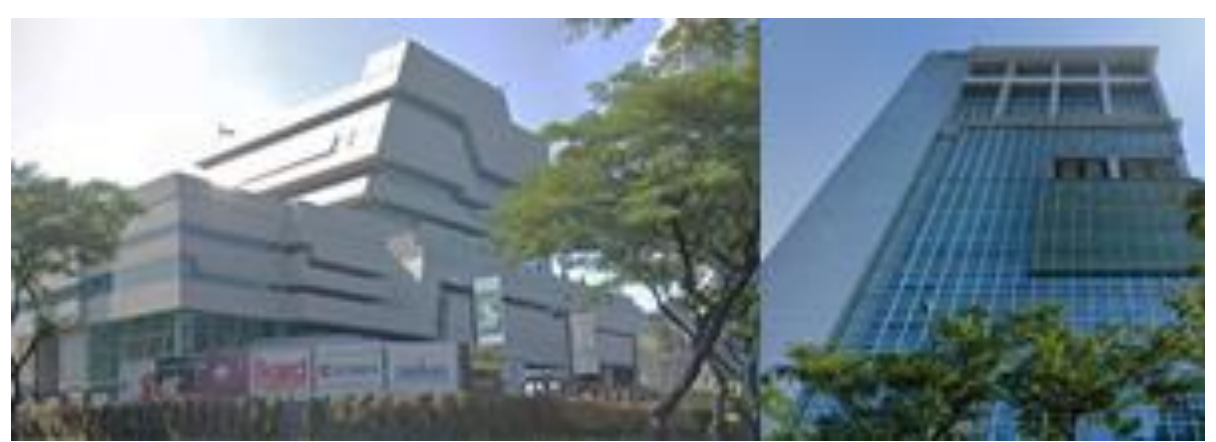

Gambar 8. Klasifikasi Khayalan yang Idealis Dunia Bangunan Sumber : Dokumentasi Pribadi, 2020

Penerapan konsep arsitektur Futuristik pada beberapa Bangunan Perkantoran yang dijadikan sebagai studi kasus pada penelitian ini . Setiap studi kasus memiliki tingkatan penerapan konsep yang dibedakan dengan jumlah tanda checklist $(\checkmark)$. Semakin banyak tanda checklist $(\checkmark)$ menunjukkan bahwa penerapan konsep semakin sesuai, dan begitupun sebaliknya. 
Tabel 1. Indikator Penerapan Konsep Arsitektur Futuristik pada Satu Studi Kasus

\begin{tabular}{|c|c|c|}
\hline $\begin{array}{l}\text { Prinsip } \\
\text { Arsitektur } \\
\text { Futuristik }\end{array}$ & $\begin{array}{c}\text { SK1 } \\
\text { Dunia } \\
\text { Bangunan } \\
\text { BSD }\end{array}$ & KESIMPULAN \\
\hline $\begin{array}{l}\text { Gerak \& } \\
\text { Kecepatan }\end{array}$ & $\checkmark$ & $\begin{array}{l}\text { Kriteria } \\
\text { Sangat } \\
\text { Populer }\end{array}$ \\
\hline Melawan Arus & $\checkmark$ & $\begin{array}{l}\text { Kriteria } \\
\text { Sangat } \\
\text { Populer }\end{array}$ \\
\hline $\begin{array}{l}\text { Kejujuran } \\
\text { Bahan }\end{array}$ & $\checkmark$ & $\begin{array}{l}\text { Kriteria } \\
\text { Sangat } \\
\text { Populer }\end{array}$ \\
\hline Dinamis & $\checkmark$ & $\begin{array}{l}\text { Kriteria } \\
\text { Sangat } \\
\text { Populer }\end{array}$ \\
\hline $\begin{array}{l}\text { Menggunakan } \\
\text { Kemajuan } \\
\text { Teknologi }\end{array}$ & & $\begin{array}{c}\text { Kriteria Cukup } \\
\text { Populer }\end{array}$ \\
\hline Nihilisme & $\checkmark$ & $\begin{array}{l}\text { Kriteria } \\
\text { Sangat } \\
\text { Populer }\end{array}$ \\
\hline Universal & $\checkmark$ & $\begin{array}{l}\text { Kriteria } \\
\text { Sangat } \\
\text { Populer }\end{array}$ \\
\hline $\begin{array}{l}\text { Khayalan } \\
\text { yang idealis }\end{array}$ & $\checkmark$ & $\begin{array}{l}\text { Kriteria } \\
\text { Sangat } \\
\text { Populer }\end{array}$ \\
\hline KESIMPULAN & $\begin{array}{c}\text { Cukup } \\
\text { Berpotensi }\end{array}$ & $\begin{array}{l}\text { Kriteria } \\
\text { Sangat } \\
\text { Populer }\end{array}$ \\
\hline
\end{tabular}

Sumber : Dokumen Pribadi, 2020

\section{Kesimpulan}

Dari penelitian yang telah dilakukan yang telah dijabarkan pada bab - bab sebelumnya, bahwa gedung dunia bangunan ini merupakan bangunan yang menerapkan prinsip arsitektur futuristk, maka dapat diperoleh beberapa poin kesimpulan sebagai berikut:

1. Arsitektur futuristik merupakan sebuah pendekatan arsitekturyang mengarah ke masa depan

2. 8 prinsip arsitektur futuristik menurut ciri futuristik dan ciri-ciri arsitektur futuristik menurut Eero Saarinen yaitu, Gerak \& Kecepatan, Melawan Arus, Kejujuran Bahan, Dinamis, Menggunakan Kemajuan Teknologi, Nihilisme, Universal , dan Khayalan yang idealis

3. Unsur Gerak dan Kecepatan Pada Studi Kasus terlihat pada garis yang menekuk memanjang yang dapat diterjemahkan sebagai gerak dan kecepatan.

4. Unsur Melawan Arus Pada Ketiga Studi kasus terlihat pada bentuk exterior bangunan serta interior bangunan yang menentang klasifikasi bangunan kantor menjadikan bangunan ini memiliki bentuk yang tidak biasa. 
5. Unsur Kejujuran Bahan dari ketiga studi kasus Terdapat pada exterior dan interior bangunan

6. Unsur dinamis pada ketiga studi kasus terlihat dari bentuk dan karakter cenderung tidak beraturan serta memiliki tatanan sudut yang bervariasi.

7. Menggunakan Kemajuan Teknologi melalui struktur dan konstruksi, menggunakan teknologi konstruksi secara ekstrim.

8. Unsur Nihilisme pada ketiga studi kasus terlihat dari Penggunaan kaca yang lebar sehingg mendapat pencapaian ruang yang polos, kosong, ataupun simpel.

9. Universal komposisi dalam satu massa bangunan terlihat bervariasi dan tidak membedakan, dan Setiap fungsi pada bangunan harus mudah dimengerti oleh penggunanya berdasarkan pengalaman, pengetahuan, bahasa, kemampuan, dan tingkatan intelektualitasnya.

10. Khayalan yang idealis terlihat dari bentuk bangunan yang membuat kebaruan dalam hal bentuknya.

\section{Ucapan Terimakasih}

Ucapan terimakasih penulis sampaikan kepada beberapa pihak yang telah mendukung penyelesaian jurnal ini:

1. Bapak Wafirul Aqli, ST., M.SC., selaku Ketua Jurusan Arsitektur.

2. Ibu Anisa, ST., MT., selaku Koordinator Seminar Tugas Akhir dan pembimbing akademik.

3. Bapak Wafirul Aqli, ST., M.SC., selaku pembimbing Seminar Tugas Akhir

4. Bapak dan Ibu Dosen Jurusan Arsitektur Universitas Muhammadiyah Jakarta, yang tidak bisa saya sebutkan satu persatu, namun tidak mengurangi rasa hormat saya.

5. Orang tua Saya yang telah memberikan doa, motivasi, nasihat dan semangat selama menempuh program Sarjana di Arsitektur FT-UMJ.

6. Seluruh pihak yang telah membantu, yang tidak dapat disebutkan satu persatu dalam penyusunan jurnal ini, Saya ucapkan terima kasih banyak.

Semoga peneltian ini dapat bermanfaat bagi perkembangan disiplin ilmu Arsitektur. Terimakasih.

\section{Daftar Pustaka}

Fauzan \& Sulistiowati, (2019). Perancangan Rental Office Di Jakarta Dengan Penerapan Arsitektur Futuristik

Krisdianto, Purwantiasning, \& Aqli, (2018). Penerapan Arsitektur Futuristik Terhadap Bangunan Gundam Base Indonesia Di Jakarta

Roby, Mauliani, \& Aqli, (2018). Konsep Futuristik Pada Perancangan Gedung Kantor Manajemen Schlumberger jakarta

Prawira, NG, \& Marlina, (2019). Pencerminan Fleksibilitas Pada Hall Gedung Convention Center Di Surakarta Dengan Konsep arsitektur Futuristik

Fachri, (2018). Taman Teknologi Tembakau Deli Di Deli Serdang "Tema : Arsitektur Futuristik"

174 I AD- Vol.01/No.02, Desember 2020 
Iskandar, (2018). Penerapan Futuristik Arsitektur Pada Bangunan Terminal Bus Terpadu Cicaheum Bandung

Anandiva \& Kurniasih, (2018). Perancangan Stadion Sepakbola Dengan pendekatan Arsitektur Futuristik Di Jakarta Timur 